Jurnal THEOREMS (The Original Research of Mathematics) Vol. 4 No. 2, Januari 2020. hal. 206-212 URL: http://jurnal.unma.ac.id/index.php/th

Naskahmasuk: 26-12-2019 Naskahdiperbaiki: 27-12-2019 Naskahditerima: 07-01-2020

\title{
ANALISIS DAYA SERAP MAHASISWA DALAM MATA KULIAH \\ PENGANTAR AKUNTANSI SEBAGAI APLIKASI ILMU MATEMATIKA
}

\section{ANALYSIS OF STUDENT ABSOLUTE POWERININTRODUCTION TO ACCOUNTINGAS A MATH SCIENCE APPLICATION}

\author{
Reva Yuliani*, Agatha Rinta Suhardi \\ ${ }^{1}$ Prodi Manajemen, Fakultas Bisnis dan Manajemen, Universitas Widyatama, Jl Cikutra 204A \\ Bandung 40125, Indonesia \\ *Email : reva.yuliani@widyatama.ac.id
}

\begin{abstract}
ABSTRAK
Penguasaan materi Pengantar Akuntansi sangat penting karena merupakan dasar dari ilmu ekonomi seperti penjurnalan, pengelompokan, pembukuan sampai dengan penyusunan laporan keuangan. Dalam prakteknya materi pengantar akuntansi ini dibutuhkan dalam sebuah bisnis tetapi mahasiswa masih sulit untuk menyiapkan laporan-laporan tersebut. Penelitian ini bertujuan untuk mengetahui perbedaan daya serap mahasiswa dalam memahami mata kuliah Pengantar Akuntasi sebagai aplikasi ilmu matematika. Sampel yang diambil yaitu dua kelas Pengantar Akuntansi di jurusan manajemen. Metode penelitian yang digunakan yaitu analisis deskriptif dengan menggunakan uji beda. Sampel dalam penelitian adalah mahasiswa manajemen yang mengambil mata kuliah Pengantar Akuntansi. Hasilnya memperlihatkan ada perbedaan daya serap pembelajaran pengantar akuntansi pada mahasiswa manajemen di kelas A dan kelas B. Hasil perbedaan ini dapat dipengaruhi oleh perbedaan metode pembelajaran yang diberikan, jumlah mahasiswa kelas B yang lebih banyak dibandingkan dengan kelas A sehinggakelas kurang kondusif dan mahasiswa kurang menyerap materi yang disampaikan.
\end{abstract}

Kata kunci: daya serap, uji beda, pengantar akuntansi

\section{ABSTRACT}

Mastery of material Introduction to Accounting is very important because it is the basis of economics such as journalizing, grouping, accounting until the preparation of financial statements. In practice this introductory accounting material is needed in a business but students are still difficult to prepare these reports. This study aims to determine differences in student absorption in understanding the Introduction to Accounting courses. Samples taken are two classes of Introduction to Accounting majoring in management. The research method used is descriptive analysis using a different test. The result is a significant difference between the introductory accounting learning outcomes of management students in class A and class B. The results of this difference can be influenced by differences in learning methods provided, the number of class B students is greater than that of class A so the class is less conducive and students are less absorb the material presented.

Keywords: absorption, different tests, introduction to accounting 
Jurnal THEOREMS (The Original Research of Mathematics) Vol. 4 No. 2, Januari 2020. hal. 206-212 URL: http://jurnal.unma.ac.id/index.php/th

Naskahmasuk: 26-12-2019 Naskahdiperbaiki: 27-12-2019 Naskahditerima: 07-01-2020

\section{PENDAHULUAN}

Dalam kegiatan belajar dan mengajar, peserta didik adalah subjek dan objek dari kegiatan pendidikan. Oleh karena itu, makna dari proses pengajaran adalah kegiatan belajar peserta didik dalam mencapai suatu tujuan pengajaran. Tujuan pengajaran akan dicapau apabila peserta didik berusaha secara aktif untuk mencapainya. Keaktifan anak didik tidak hanya dituntut dari segi fisik, tetapi juga dari segi kejiwaan. Apabila hanya dari segi fisik saja yang aktif dan mentalnya tidak aktif, maka tujuan dari pembelajaran belum tercapai. Hal ini sama saja dengan peserta didik tidak belajar, karena peserta didik tidak merasakan perubahan dalam dirinya. Belajar pada hakikatnya adalah suatu "perubahan" yang terjadi dalam diri seseorang setelah melakukan aktivitas belajar.

Menurut Hans Freudental (Zubaidah Amir \& Risnawati, 2016:9), matematika merupakan aktivitas insani dan harus dikaitkan dengan realitas. Dengan demikian, matematika merupakan cara berpikir logis yang dipresentasikan dalam bilangan, ruang, dan bentuk dengan aturan-aturan yang telah ada yang tak lepas dari aktivitas insani tersebut. Pada hakikatnya, matematika tidak terlepas dari kehidupan sehari-hari. Semua masalah kehidupan yang membutuhkan pemecahan secara cermat dan teliti mau tidak mau harus berpaling kepada matematika.

Untuk dapat mempelajari ilmuilmu, pastinya kita perlu memahami arti dan tujuan dari ilmu yang akan kita pelajari. Salah satunya adalah ilmu akuntansi. Sangat penting diketahui dan dipahami mengenai konsep dasar dari akuntansi. Secara umum, akuntansi berarti suatu proses mencatat, mengklasifikasi, meringkas, mengolah dan menyajikan data, transaksi serta kejadian yang berhubungan dengan keuangan sehingga dapat digunakan oleh orang yang berkepentingan dengan mudah dimengerti untuk pengambilan suatu keputusan serta tujuan lainnya. Jika pengertian tersebut telah benarbenar dipahami dengan baik, maka akan mudah mempelajari poin-poin selanjutnya dari akuntansi

Akuntansi merupakan proses sistematis untuk mengolah transaksi menjadi informasi keuangan yang bermanfaat bagi para penggunanya (Warsono et al. 2010). Laporan keuangan merupakan output yang dihasilkan dari proses akuntansi. Laporan keuangan digunakan sebagai salah satu.

Menurut Hans Kartikahadi, dkk. (2016:3) pengertian akuntansi adalah : "Akuntansi adalah suatu sistem informasi keuangan, yang bertujuan untuk menghasilkan dan melaporkan informasi yang relevan bagi berbagai pihak yang berkepentingan"

Bahan untuk pengambilan keputusan perusahaan. Laporan keuangan menghasilkan informasi yang bermanfaat bagi penggunanya, antara lain yaitu: informasi kinerja keuangan perusahaan, informasi perubahan jumlah modal pemilik dalam suatu perusahaan, informasi posisi keuangan perusahaan terkait dengan sumber dana dan jenis penggunaan dana, dan informasi pemasukan aliran kas perusahaan (Sagoro, 2015). Setiap mahasiswa sebagai calon tenaga penyusun laporan keuangan atau sebagai pemilik perusahaan harus mampu menyusun laporan keuangan secara tepat. Kemampuan menyusun laporan keuangan diperlukan mahasiswa agar mereka mampu menghasilkan laporan keuangan yang memuat informasi keuangan secara 
Jurnal THEOREMS (The Original Research of Mathematics) Vol. 4 No. 2, Januari 2020. hal. 206-212 URL: http://jurnal.unma.ac.id/index.php/th

Naskahmasuk: 26-12-2019 Naskahdiperbaiki: 27-12-2019 Naskahditerima: 07-01-2020

akurat. Namun, pada kenyataanya tidak semua mahasiswa memiliki kemampuan yang memadai untuk menyusun laporan keuangan. Kemampuan mahasiswa khususnya yang tidak memiliki latar belakang pendidikan akuntansi, kemampuan mereka dalam menyusun laporan keuangan sebagian besar rendah.

Peran akuntansi pada sebuah perusahaan tentu sangat diperlukan karena setiap perusahaan membutuhkan proses pengolahan data yang akurat sehingga menunjang operasional perusahaan. Pengantar akuntansi diartikan sebagai pengukuran, penjabaran atau pemberian kepastian mengenai informasi yang akan membantu manajer, investor, otoritas pajak dan pembuat keputusan lain dalam pengalokasian sumber daya, pengambilan keputusan. Akuntansi yaitu suatu sistem informasi keuangan yang bertujuan menghasilkan dan melaporkan informasi yang relevan bagi berbagai pihak yang berkepentingan (Kartikahadi, 2016).

Akuntansi mengekspresikan hubungan komponen-komponen ini dalam persamaan akuntansi (Weygandt, 2016). Persamaan akuntansi yaitu Aset = Kewajiban/Hutang + Ekuitas/Modal. Kewajiban atau hutang dalam persamaan akuntansi ditempatkan sebelum ekuitas/modal sebab kreditor yang paling pertama berhak mendapat pengembalian hutang pada saat terjadi likuidasi atau kebangkrutan (Weygandt, 2016).

Mata kuliah Pengantar Akuntansi wajib ditempuh oleh mahasiswa jurusan manajemen, merupakan suatu keharusan bagi mahasiswa untuk memahami materi pengantar akuntansi karna bukan hanya bermanfaat untuk diri sendiri tetapi dalam sebuah bisnis pun sangat dibutuhkan. Banyak mahasiswa yang baru saja mendengar mata kuliah pengantar akuntansi beranggapan bahwa materi tersebut sangat sulit mulai dari proses pencatatan, penjurnalan, pembukuan ke dalam buku besar sampai dengan pembuatan laporan keuangan sehingga dapat memberikan informasi bagi pihak internal maupun eksternal.

Menurut Hans Kartikahadi, dkk. (2016:12) Laporan Keuangan adalah : "Media utama bagi suatu entitas untuk mengkomunikasikan informasi keuangan oleh manajemen kepada para pemangku kepentingan seperti : pemegang saham, kreditur, serikat pekerja, badan pemerintahan, manajemen".

Laporan keuangan merupakan hasil dari proses akuntansi yang terdiri dari Laporan Laba Rugi, Laporan Perubahan Ekuitas, Laporan Posisi Keuangan, Laporan Aliran Kas, dan Catatan Atas Laporan Keuangan (Suwardjono, 2002; Warsono, 2009; Weygandt et al, 2012; Sagoro, 2015). Pada penelitian ini, laporan keuangan yang menjadi objek penelitian terbatas pada laporan laba rugi, laporan perubahan ekuitas, dan laporan posisi keuangan. Ketiga laporan keuangan tersebut merupakan laporan yang dapat segera disusun ketika mahasiswa telah mengerjakan neraca lajur (kertas kerja). Sebelum mahasiswa menyusun laporan keuangan, mahasiswa harus mampu menyusun neraca lajur secara tepat sehingga diharapkan pada saat penyusunan laporan keuangan tidak terjadi kesalahan. Hal ini berarti bahwa kompetensi menyusun laporan keuangan merupakan kemampuan untuk mengerjakan atau menyusun neraca lajur dan menggunakan datadata dalam neraca lajur tersebut untuk menyusun laporan laba rugi, laporan 
Jurnal THEOREMS (The Original Research of Mathematics) Vol. 4 No. 2, Januari 2020. hal. 206-212 URL: http://jurnal.unma.ac.id/index.php/th

Naskahmasuk: 26-12-2019 Naskahdiperbaiki: 27-12-2019 Naskahditerima: 07-01-2020

perubahan ekuitas, dan laporan posisi keuangan.

Informasi berupa laporan keuangan dihasilkan melalui proses akuntansi yang panjang. Pada proses tersebut terdapat tahap-tahap yang harus dipenuhi untuk mendapatkan hasil laporan yang baik, valid dan akuntabel. Tahap-tahap itulah yang kemudian disebut sebagai siklus akuntansi.

Siklus akuntansi terdiri dari beberapa tahapan diantaranya :

1. Mencatat seluruh transaksi sesuai dengan kronologi menjadi Jurnal Umum.

2. Memindahkan (Posting) transaksi akuntasi dari jurnal umum ke buku besar (Ledger).

3. Menyusun Neraca Saldo

4. Membuat Jurnal Penyesuaian.

5. Menyusun Neraca Saldo setelah Penyesuaian.

6. Menyusun Laporan Berdasarkan Neraca Saldo Setelah Penyesuaian.

Setelah mahasiswa mengerjakan semua tahapan dari siklus akuntansi barulah informasi bisa di dapatkan dan disusun menjadi sebuah laporan. Laporan yang disajikan yaitu Laporan Neraca, Laporan Laba Rugi dan Laporan Perubahan Modal.

\section{METODE PENELITIAN}

Metode penelitian menurut Sugiyono (2017:2) diartikan sebagai cara ilmiah untuk mendapatkan data dengan tujuan dan kegunaan tertentu. Dalam penelitian ini metode penelitian yang digunakan adalah metode penelitian kuantitatif. Menurut Sugiyono (2018:3536) metode kuantitatif adalah sebagai berikut: "Metode penelitian kuantitatif dapat diartikan sebagai metode penelitian yang berlandaskan pada filsafat positivisme, digunakan untuk meneliti populasi atau sampel tertentu, pengumpulan data menggunakan instrumen penelitian, analisis data bersifat kuantitatif/statistik, dengan tujuan untuk menguji hipotesis yang telah ditetapkan."

Penelitian ini yaitu penelitian kualitatif dan strategi penelitiannya menggunakan analisis deskriptif kualitatif. Adapun pengambilan data menggunakan metode tes dan wawancara. Tes dilakukan setelah mahasiswa mendapatkan pembelajaran secara langsung mengenai materi Pengantar Akuntansi. Untuk wawancara dilakukan sebagai bentuk konfirmasi atas jawaban mahasiswa. Penelitian ini dilaksanakan di suatu Perguruan Tinggi Swasta di Bandung pada bulan Oktober 2019. Populasi yang digunakan yaitu mahasiswa jurusan manajemen kelas A dan B, sampel diambil secara purposive sampling sejumlah 81 mahasiswa dengan mempertimbangkan hasil jawaban tes mahasiswa.

Penelitian berupa tes tertulis yang dibuat oleh peneliti dengan mempertimbangkan validitas isi serta muka kepada para ahlinya yaitu seluruh dosen yang mengampu mata kuliah Pengantar Akuntansi.

Teknik analisis data yang digunakan dengan uji beda.Instrumen penelitian terdiri atas 3 soal essay mengenai materi pengantar akuntansi, contoh soal yang diberikan sebagai beirkut :

1. Buatlah jurnal umum dari Perusahaan tersebut?

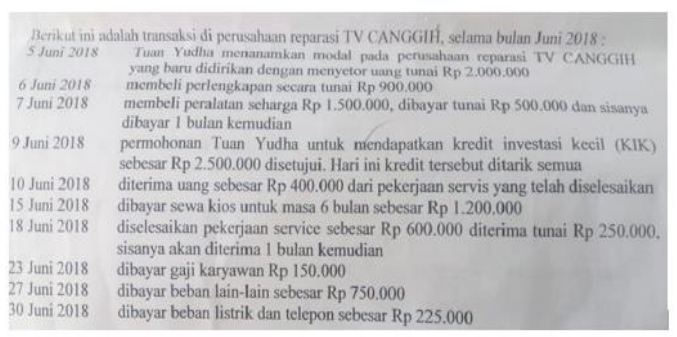

Copyright $@ 20 x x$, Jurnal THEOREMS (The Original Research of Mathematics)

p-ISSN: 2528-102X, e-ISSN: 2541-4321, URL:http://jurnal.unma.ac.id/index.php/th 
Jurnal THEOREMS (The Original Research of Mathematics) Vol. 4 No. 2, Januari 2020. hal. 206-212 URL: http://jurnal.unma.ac.id/index.php/th

Naskahmasuk: 26-12-2019 Naskahdiperbaiki: 27-12-2019 Naskahditerima: 07-01-2020

2. Buatlah kertas kerja Laporan Keuangan

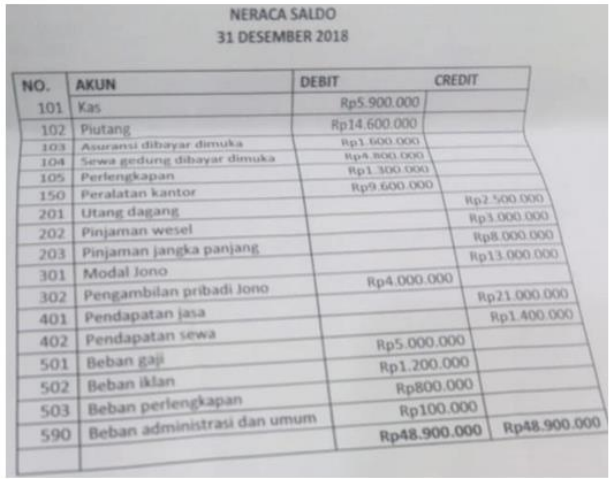

3. Buatlah ayat jurnal penyesuaian yang berhubungan dengan transaksi di bawah

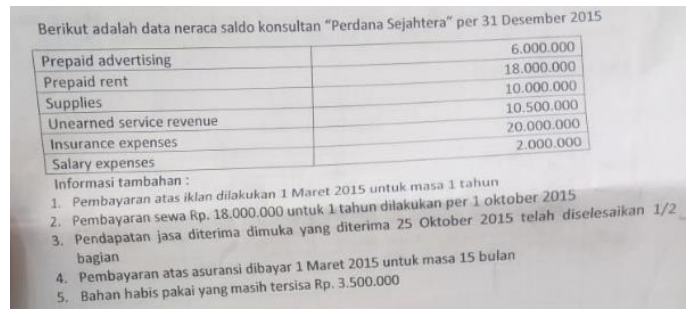

Dari soal yang diberikan kepada mahasiswa jawaban yang dikerjakan oleh mahasiswa kelas A dan kelas B memiliki jawaban yang berbeda.

\section{HASIL DAN PEMBAHASAN}

Tabel 1

Jumlah Mahasiswa Kelas A dan B

\begin{tabular}{|c|c|c|r|}
\hline No & Kelas & $\begin{array}{c}\text { Jumlah } \\
\text { Mahasiswa }\end{array}$ & $\begin{array}{c}\text { Nilai } \\
\text { Tertinggi }\end{array}$ \\
\hline 1 & A & 36 & 93 \\
\hline 2 & B & 45 & 75 \\
\hline
\end{tabular}

Sumber : Data pengolahan (2019)

Berdasarkan hasil tabel 1.1 dapat disimpulkan bahwa jumlah kapasitas mahasiswa yang mengambil mata kuliah pengantar akuntansi berbeda, kapasitas jumlah mahasiswa kelas A sebanyak 36 orang sedangkan untuk kelas B lebih banyak sebesar 45 orang, dari hasil analisa tersebut terlihat bahwa kelas A lebih kondusif dibandingkan kelas B dimana kelas A lebih baik dalam menyerap materi pengantar akuntansi.

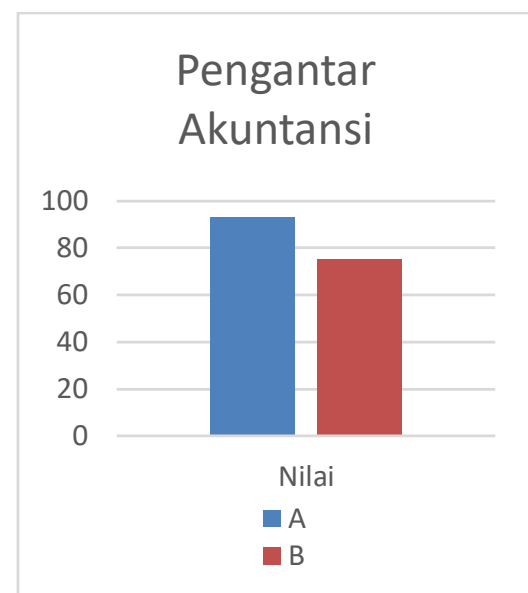

Gambar 1.

Nilai Kelas A dan B

Berdasarkan gambar diatas dapat disimpulkan hasil nilai pengantar akuntasi kelas A dan B berbeda, Nillai kelas A lebih tinggi di bandingkan dengan kelas B. Selain itu hasil pengujian uji Beda metode pembelajara pengantar akuntansi pada kelas A dan kelas $\mathrm{B}$ didapat sebagai berikut :

Tabel 2

Uji Beda

\begin{tabular}{|l|c|c|c|c|}
\hline Kelas & N & Mean & $\begin{array}{c}\text { Std. } \\
\text { Deviation }\end{array}$ & $\begin{array}{c}\text { Std. } \\
\text { Error } \\
\text { Mean }\end{array}$ \\
\hline Hasil & & & & \\
PA A & 36 & 68.8611 & 19.04004 & 3.17334 \\
PA B & 45 & 60.4889 & 12.25231 & 1.82647 \\
\hline
\end{tabular}

Sumber : Pengolahan Data (2019)

Berdasarkan hasil pengujian statistik yang diperoleh rata-rata statistik kelas A dengan jumlah mahasiswa 36 orang sebesar 68.8611 dan kelas B dengan jumlah mahasiswa 45 orang sebesar 60.4889. Dengan demikian didapat bahwa ada perbedaan 
Jurnal THEOREMS (The Original Research of Mathematics) Vol. 4 No. 2, Januari 2020. hal. 206-212 URL: http://jurnal.unma.ac.id/index.php/th

rata-rata hasil belajar mahasiswa kelas A dan kelas B. Langkah berikutnya, untuk membuktikan apakah perbedaan tersebut signifikan atau tidak maka digunakan Independent Sample Test.

Independent Sample Test menunjukkan bahwa nilai sig. Levene's Test for Equity of Variances sebesar 0,433 lebih besar dari 0,05 yang artinya variansi antara kelas A dan kelas B adalah sama atau homogen (Sujarweni, 2014), dan hasil equal variances assumed diketahui nilai sig. (2-tailed) sebesar 0,019 lebih kecil dari 0,05 yang artinya terdapat perbedaan hasil pembelajaran mata kuliah pengantar akuntansi pada mahasiswa jurusan manajemen antara kelas A dan kelas B, degan adanya hasi perbedaan diantara kelas tersebut artinya penerapan aplikasi matematika pada mahasiswa yang mengambil mata kuliah pengantar akutansi perlu di berikan banyak latihan soal mengenai matematika karena matematika merupakan aktivitas yang harus dikaitkan dengan realitas. Dimana mahasiswa harus bisa berpikir secara logis yang akan dipresentasikan dalam bilangan akuntansi.

\section{KESIMPULAN}

Ada perbedaan hasil pembelajaran mata kuliah pengantar akuntansi pada mahasiswa jurusan manajemen kelas $\mathrm{A}$ dan kelas B. Hasil perbedaan ini dapat dipengaruhi oleh perbedaan metode pembelajaran yang diberikan, jumlah mahasiswa kelas B lebih banyak dibandingkan dengan kelas A sehingga kelas menjadi kurang kondusif dan mahasiswa kurang menyerap materi perkuliahan yang disampaikan.

\section{SARAN}

Mahasiswa selalu menganggap bahwa mata kuliah pengantar akuntansi merupakan materi yang sulit dan sangat tidak disukai. Pemikiran ini yang sangat mempengaruhi sikap mahasiswa dalam penerimaan materi yang dibahas di kelas sehingga mahasiswa perlu untuk menggeser pola pikir bahwa pengantar akuntansi mudah karena informasi yang dihasilkan berkaitan dengan pengambilan keputusan.

Selain itu bagi dosen yang mengajar mata kuliah hitungan atau kuntitatif sebaiknya memiliki metode khusus dalam penyampaian materi selain itu mahasiswa harus sering diberikan latihan soal agar terbiasa dalam mengerjakan soal hitungan karena apabila tidak sering diberikan latihan biasanya mahasiswa kurang menyerap materi yang disampaikan.

\section{DAFTAR PUSTAKA}

[1] Sodikin, S.S. dan Riyanto, B.A. (2016). Akuntansi Pengantar 1. Edisi kesembilan. Yogyakarta: UPP STIM YKPN.

[2] Suwardjono. (2014). Akuntansi Pengantar Bagian 1: Proses Penciptaan Data dan Pendekatan Sistem. Edisi ketiga. Yogyakarta: BPFE.

[3] Warren, C.S., dkk. (2014). Financial and Managerial Accounting. 12 $2^{\text {th }} E d$. USA: South-Western, Cengage Learning.

[4] Weygandt, J.J., dkk. (2016). Accounting Principle. $12^{\text {th }} \mathrm{Ed}$. New Jersey: John Willey \& Sons Inc.

[5] Layn, Muhamad Ruslan\&Kahar, Muhammad Syahrul. (2017). Analisis Kesalahan Siswa Dalam Menyelesaikan Soal Cerita Matematika. Jurnal Math Educator 
Jurnal THEOREMS (The Original Research of Mathematics) Vol. 4 No. 2, Januari 2020. hal. 206-212 URL: http://jurnal.unma.ac.id/index.php/th

Naskahmasuk: 26-12-2019 Naskahdiperbaiki: 27-12-2019 Naskahditerima: 07-01-2020

Nusantara (JMEN), Vol. 3 No. 2 pp. 95-102.

[6] Manibuy, Ronald. (2014). Analisis Kesalahan Siswa dalam Menyelesaikan Soal Persamaan Kuadrat Berdasarkan Taksoomi Solo padaKelas X SMA Negeri 1 Plus di KabupatenNabire-Papua. Jurnal Elektronik Pembelajaran Matematika, Vol. 2 No. 9.

[7] Nurianti, Evi, Halini, Romal. (2015). Analisis Kesalahan Siswa Dalam Menyelesaikan Soal Matematika Materi Pecahan Bentuk Aljabar Di Kelas VIII SMP. Jurnal Pendidikan dan Pembelajaran, Vol. 4 No. 9 pp. 61-70.

[8] Tall, D., \& Razali, M. (1993). Diagnosing Stucents' Difficulties in Learning Mathematics. International Journal of Mathematics Education in Science \& Technology, Vol. 24 pp 209-212.

[9] Toheri \& Astinawati, I. (2011). Pengaruh Penguasaan Aljabar terhadap Kemampuan Siswa dalam Menyelesaikan Soal - Soal Bangun Ruang. Jurnal Eduma, Vol. 1 No. 1 pp. 1-8.

[10] Suhardi, Agatha Rinta\& Lestari, Puji. (2019). Analisis Kesalahan Mahasiswa Manajemen Dalam Menyelesaikan Permasalahan Analisis Titik Impas. Jurnal Theorems(The Originals Research of Mathematics), Vol. 4 No. 1 pp. 60-68

[11] Kartihadi, Hans. dkk. (2016). Akuntansi Keuangan Berdasarkan SAK Berbasis IFRS. Jakarta:IAI.

[12] Amir Zubaidah dan Risnawati. 2016. Psikologi Pembelajaran
Matematika. Yogyakarta: PT Plosokuning.

[13] Hans Kartikahadi., dkk. 2016. Akuntansi Keuangan Berdasarkan SAK Berbasis IFRS Buku 1. Jakarta : Salemba Empat.

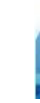

